\title{
Information Technology Applications in the Material Handling Industry
}

\author{
Virginia Anne Taylor \\ William Paterson University, Wayne, New Jersey
}

\author{
taylorv@wpunj.edu
}

\begin{abstract}
This study is an exploratory review of the determinants and extent of information technology's influence on the operations of material handling dealerships in the USA. The goal is to develop an analysis framework specifying which factors contribute to the transformation of the material handling industry's practices in relation to using information technology to optimize transactions in goods, knowledge, and services. Knowledge management, sales force automation, customer relationship management, demand chain management, customer service automation, inventory management, and enterprise resource planning, will be investigated. A survey instrument will be used to elicit both information technology ideas that have already changed operations and those that are expected to impact future approaches to informing clients effectively and efficiently. The primary objectives of this research are to identify relevant issues, develop a pilot case study, and provide an analysis of the participant's responses to an initial survey questionnaire about these topics.
\end{abstract}

Keywords: knowledge management, sales force automation, customer relationship management, demand chain management, customer service automation, inventory management, enterprise resource planning

\section{Introduction}

The general purpose of this research is to uncover insights on how information technology has affected the material handling industry. The presentation will attain its purpose and objective as follows: it will begin with a discussion of the important elements followed by application of elements to factual settings thereby exemplifying the issues within a case study approach. This will be followed by an analysis of the empirical research.

Like the traditional factors of production - land, labor, and capital, knowledge is an asset, a corporate resource. In the materials handling industry there are always two or more knowledge and information technology bases to be covered, those controlled by the suppliers and those controlled by the customers and potential customers. Issues of integration and proprietary rights may collide, confuse or create opportunities for innovation at any given point in the ongoing relationship between supplier and client. Knowledge management has become a cornerstone of competitiveness and success due to the increasingly complex problems that global corporations face today. Successful knowledge management blends technological,

Material published as part of these proceedings, either on-line or in print, is copyrighted by Informing Science. Permission to make digital or paper copy of part or all of these works for personal or classroom use is granted without fee provided that the copies are not made or distributed for profit or commercial advantage AND that copies 1) bear this notice in full and 2) give the full citation on the first page. It is permissible to abstract these works so long as credit is given. To copy in all other cases or to republish or to post on a server or to redistribute to lists requires specific permission from the publisher at Publisher@InformingScience.org sociological and psychological knowledge. Technological solutions sometimes ignore the vital nontechnology issues - people, processes and politics. The failure of sales force automation technology is a case in point. While sales personnel may now be called consumer relationship managers, there is still an unstructured aspect to the nature of this type of work which makes it hard to get anyone in the sales 
or customer relationship management field to use sales information technology consistently (Tuck, 2001). Individuals employed in the materials handling industry in sales and distribution functions are viewed as customer relationship managers in this study.

\section{Research Methodology}

The first part of this study investigates the trade literature to discover possible elements for a study of information technology adoption in the material handling industry. The seven elements uncovered are presented in the first part of the paper; the second part of this research consists of a pilot case study of an individual lift truck dealership. The dealer principal agreed to the case study and provided access to the involved employees. For the initial case study the goal was to discover which of the currently available information technology techniques have been actively considered for implementation, which have been tried and which elements are actually in use at the present time. In the third stage of this research the results of this pilot case study will be incorporated into a survey instrument that will serve as the basis for directed interviews of a select group of dealer principals at the annual MHEDA (Material Handling Equipment Distributors Association) meeting in April, 2002. The purpose of these interviews is development of a redesigned survey instrument suitable for distribution to a wider dealership population in the near future. Four propositions are at the center of the research at each stage and will be called out most clearly at the design stage of the final survey instrument.

\section{Customer Relationship Management}

Customer relationship management cuts across marketing, sales and service and has key dependencies in production planning, inventory management, and financial functions as well as in distribution \& logistics. The underlying basic premise is that it is easier to generate more business with existing customers than it is to acquire new ones. A happy customer is a great asset. Customer service automation can provide recommendations based on customer's profile data and in house and customer access to current account information. System success depends on both people and technology. Trained and empowered representatives need the ability to share company data screens via the Internet with customers during service interactions (Pechi, 2001).

Demand chain management, sometimes called tanpin kanri, was pioneered in Japan's Seven-Eleven stores. It empowers retail clerks to tweak suggested assortments. These front line workers are in a position to know how things like the neighborhood weather or a local soccer event will impact the firm's store by store, product by product demand. An important component is state-of the-art software and terminals which provide relevant information and communication capabilities. The data can be analyzed to uncover customer trends. Understanding when peaks in demand will occur benefits the company with reduced inventory costs and satisfies the customer with reduced out-of- stock problems. (Costello, 2001). Analytic analysis of your customer $\&$ demand chain automation technologies has the potential to change the way many industries do business (Hall, 2001). In the materials handling industry, lift truck dealerships could utilize their basic customer database to let their customers know that they sell replacement parts, accessories and tires as well as forklifts and thereby increase the potential of significant revenue from aftermarket sales.

Data integration is desirable to provide a single accurate view, help to assess what might happen in the future as well as to reduce the danger of business unit decisions that make no effort to gain real insight into the overall impact of their actions. Enterprise resource software offers across the board connectivity; but many complain about lengthy implementation times (Compton, 2001). Connectivity must be evaluated against applications with the best capability for a specific solution. Complete understanding of complexities in enterprise resource planning is impossible to achieve without a solid analytical framework. The multidisciplinary nature of knowledge and the enormous volume of data to be managed present in- 
formation technology challenges for both the business owner and an increasingly mobile workforce. Crafting an analytical strategy begins with defining an appropriate scope to discover which analytical tools can help reduce marketing risk and increase profitability in this industry.

\section{Pilot Case Study}

\section{Background}

Both the materials handling industry in general and the fork lift truck segment in particular are global industries, with volume production occurring both within and outside of the United States. The market for the product is also global. There have been product modifications within in the industry to meet domestic standards like OSHA and EL requirements and the regional ISO900 standards in Europe. A number of foreign equipment manufacturers have set up production facilities inside the USA as a result of either threatened and/or enforced dumping duties. NAFTA has also encouraged more investment in North American production facilities. Most OEMs employ a global production strategy and focus on cost minimization. Over the years new technology has made low cost labor a less important factor. This trend to capital intensive production methods has resulted in intensified competition. Large sales volume is needed to attain low marginal cost benefits associated with automated manufacturing.

Some manufacturers specialize in narrow isle equipment. Some seek to be full line suppliers everywhere they do business. Others may offer only a limited lineup of forklift truck sizes for sale in the USA while supplying a broader line to other markets in Europe and Asia. This is a cyclical industry that is coming off a terrible downturn after two record years. The last major downturn was in the early 1990s. Overcapacity exists; consolidation and strategic alliances are expected to continue.

Some OEM "national account" applications do exist. Sales and service distribution channels are generally geographically organized rather than by product line or industry specific sales. In the forklift truck industry equipment is either is leased or sold to distributors who in turn develop venues for the sale or rental of the product in their service area. A dealer/distributor may have several dealership locations. Sometimes the product is also sold directly to companies that have a need for the product on a large volume or recurring basis. Over the last ten years some of these national account/ rental companies have created competition for the local dealership. Given the competitive nature of the industry profit margins are low although bonuses, discounts, and vacation rewards for achieving an increased market share or high volume of sales are common at both the manufacturer and dealership levels. Since the product is often used to move inventory, any economic downturn that reduces a company's production and inventory has an impact on the materials handling industry. A small account might purchase or lease ten items a year, and a large account could purchase or lease several hundred. The range is akin to the difference between a "mom and pop grocery store" and a supermarket chain. Even positive economic uncertainty can cause problems for a dealership. "Growing pains" occur when sudden increases in sales volume create large supplier payables, accounts receivable, inventory holding costs, and overtime payroll. Sometimes good sales dealerships that have not expanded their credit lines experience severe cash problems. Poor forecasting can bankrupt them.

\section{Subject}

The individual dealer principal who is the subject of the pilot study represents a client slightly below the midpoint of the scale with respect to size of the operation and is growing. This group recently opened for business in a second location about forty miles away from the home location. The dealer's son is working out of a building rented from the retired ex-dealer in the new area. They have been in the business of sales, leasing, and maintenance of materials handling equipment for more than twenty years. This dealer grew up with a wrench in his hand and inherited his dealership from his father. He has maintained a rela- 
tionship with this manufacturing company for over fifteen years and for most of that time, has dealt with the same regional sales representative.

\section{Case}

Several aspects of the manufacturer's business are automated. Employees are encouraged to use company wide email rather than memos. Three years ago, when a new president took over, the regional managers and corporate executives were supplied with portable computers so they can stay in touch with the home office. The company webpage was designed with hyper links to various products and services. Some links are available to the general public; others (inside price lists) are password protected for company dealers and personnel. Real time reduction information is now on the computer; but still not web available below the top management levels. One must ask for expected delivery times.

The manufacturer would like to automate each of the areas named here but not necessarily in this order. All customer contact, (sales calls, quotes, billing, delivery reports, warranty requests, and complaints) for national accounts, dealer principals, sales, service, and parts managers.

Some aspects of the fork lift truck dealership's business have also been automated. Accounting services were the first to be automated. At the request of the outside accountant, they began to use a software program for billing, receivables, and payroll. They have a statistical package that uses historical data to computer generate estimates of time \& dollar for service jobs. The dealer uses this for both quotes and evaluation of service employees. In addition, the dispatching of service trucks is automated

The dealership would like to automate some other areas named here, but, not necessarily at once or in this order. He has recently considered the purchase of a Quote- maker software product that will let him electronically generate a quotation based on the manufacturer's price book and the dealer's associated discounts and profit margins.

Interviews at the MHEDA conference are expected to add significant information and insight into the culture of automation in the fork lift industry. This material will be incorporated into the survey instrument to be developed in the next stage of the research.

\section{Survey Propositions}

In the redesigned survey four information technology-focused propositions will be investigated in the materials handling equipment environment, thus offering the opportunity for an increased understanding of the dynamics of information technology integration in industry. These propositions are:

\section{Proposition \#1: Some information technologies are more widely used than others.}

This proposition suggests that adoption differences are expected to exist. The researcher believes some technologies will be used by a greater number of dealerships and others will be used less frequently. A review of the recent trade literature suggests that proposition $\# 1$ is true.

\section{Proposition \#2: Some information technologies have been considered/adopted and abandoned.}

At this stage in the research proposition \#2 is exploratory. No prediction or opinion is offered about whether or not dealerships use different information technologies on a trial basis. The trade literature suggests those information technologies that deal with sales and customer service have special problems associated with the nature of the work (Tuck, 2001). They may have been abandoned, adjusted, or simply taken longer to implement. The speed of implementation has a direct affect on payback and ROI (Bush- 
nell, 2001). Other scenarios also exist. A firm may decide to replace existing systems to gain more advanced capabilities (Kehley, 2001).

The recession economy last year with ITA numbers down significantly (Bartecki, 2001) increased the pressure to cut costs (Forger, 2001). Since inventory and receivables management make up slightly more that $60 \%$ of the typical MHEDA dealership's assets (Bates, 2001), they may be early targets for information technology investment to control costs.

\section{Proposition \#3: The size of a dealership influences the information technology decisions.}

High volume dealerships and those with multiple operations would have more customers, employees, and transactions. Economy of scale theory supports the view that capital investment in any technologies is related to volume (Ortega, 2001). Therefore the size factor addressed in proposition \#3 is expected to have a positive relationship with increased investment in information technologies. However, web application hosting may make scale economies less important in the future (Baker, 2001)

\section{Proposition \#4: The original equipment manufacturer relationship influences IT decisions.}

This proposition deals with the possible influence of original equipment manufacturers (OEM) on dealer principal's decisions to adopt or not to adopt certain information technologies. For example, the OEM may require all dealerships associated with the organization to use a common software package to encourage more information sharing up and down the supply chain (Kehley, 2002). Proposition \#4 is expected to be true.

\section{Concluding Remarks}

There is evidence from the pilot study that the typical material handling industry relationship between producer and distributor or purchaser is replete with behaviors that are not congruent with the rapid acceptance by either party of an integrated information technology system. Competition, cost issues and customer independence mitigates against the design of any system that depends on proprietary information. However, there is a wide stream of data that can be used by each and can be the source of innovative information technology designs. A directed interview and survey approach will be used to uncover the attitudes, adoption, and implementation plans for knowledge management (KM), sales force automation (SFA), customer relationship management (CRM), demand chain management, (DCM), customer service automation (CSA) inventory management (IM) and enterprise resource planning (ERP). The research questionnaire will investigate attitudes about and the degree to which automation software and other information technologies and techniques have been adopted for each of the seven areas by material handling executive principals and sales managers at lift truck dealerships in the USA. It will also seek to uncover areas for manufacturer- sales representative-dealer cooperation that feature information technology.

\section{References}

Baker, S. (2001). Web application hosting market growing at 57\%. Modern Materials Handling, September, 21.

Bartecki, G. (2001). Were things that different in 1990? The numbers speak for themselves. The MHEDA Journal, 30: 4, 115.

Bates, A. (2001). The profit gap. The MHEDA Journal, 30:4, 113-115.

Bushnell, R. (2001). A fresh look at software speed. Modern Materials Handling, November, 35.

Compton, J. ( 2002). CRM Vendors Promise Rapid Rollouts. CRM, October, 16-18. 
Information Technology Applications

Costello, D. (2002). Demanding more: Japan's Seven-Eleven stores up sales with tanpin kanri. CRM,_October.

Dickie, J. (2001). Analyze your sales process first. CRM, October, 28-29.

Forger, G. (2001). Make some good news. Modern Materials Handling, November, 15.

Hall, L. Hyster. (2001). Company goes to the brickyard 400- interview with Lee Hall, director of product support marketing at Hyster Sales Company. The MHEDA Journal, $30: 4,41$.

Kehley, R.. (2001). Interview with Robert Kehley, vice president Key Material Handling, Brooklyn, NY in August, 2001.

Ortega, R. (2002). Interview with Raymond Ortega , President of Profift Inc., Asbury Park, NJ in Februrary, 2002.

Pechi, T. ( 2001). Sublime Service. CRM, October, 25-26.

Tuck, L., (2001). One foot in front of the other. CRM October, 10.

\section{Biography}

Virginia Anne Taylor is the Director of Graduate Studies/ MBA Program at the Cotsakos College of Business, William Paterson University in Wayne, NJ, USA, where she is an Associate Professor in the Department of Marketing \& Management. Her doctorate In International Business Administration is from the Fox School of Business and Management at Temple University. Her publications focus on the design of multinational control systems, global strategy and transfer pricing, international business ethics, government and business perceptions of value, location determinants for value-added activities, decision support paradigms, technology's impact on the workplace and education, and active learning pedagogy. 